第 19 回 日本臨床薬理学会 1998 年 11 月 20 21 日 大分

シンポジウム $2 ：$ 新 GCP 下でのデータマネジメントのあり方

\title{
6．多施設共同臨床試験とデータマネジメント
}

\author{
新 美 三由紀* 福 田 治 彦*
}

治験、市販後臨床試験、医師主導型臨床試験 などの臨床試験の種類によらず、意味のある結 論を導くのに必要な症例数を限られた時間内に 集積することは重要である。いかにすぐれた理 念に基づく試験であっても、時間がかかり過ぎ ては試験の意義自体が損なわれてしまう。そこ で、単独の医療機関では必要な症例集積が見込 めない場合に、複数の医療機関から集積を行う

「多施設共同臨床試験： cooperative multicenter trial」が行われることになる。

多施設共同臨床試験を行うことの利点は、こ うした速やかな症例の集積が主であるが、その 他にも得られた結果を対象となる母集団に外㨉 する際の信頼性（外的妥当性）の向上、試験 ザインや管理のノウハウといった方法論の進歩 があげられる。しかし、一方で問題点も多い。 参加施設が多くなればなるほど企画や管理は複 雑になり、当然費用もかかる。また、必ずしも 積極的でない施設が增えることで責任が分散し、 時には試験そのものがマンネリ化したり、妥協 の産物と化してしまう危険性もあるだろう。デ ータマネージメントという観点からは、施設間 差が最も問題となる。

【臨床試験における施設間差】

我が国における施設間差の多くは、データマ ネージメントの技術的未熟さと施設側の臨床試

* 国立がんセンター研究所がん情報研究部 于 104-0045 東京都中央区築地 5-1-1
験インフラの未整備が主な原因であると思われ る。この施設間差は、多施設共同臨床試験の運 営や品質管理において非常に重要な問題である が、これを無くすことは不可能である。存在す ることを前提に、それが結果の解釈や結論の信 頼性に及ほす影響を十分に認識した上で、試験 の計画や品質保証、結果の解釈を行うという視 点が必要である。

具体的にデータマネージメント上問題となる 施設間差には、(1)登録症例数、(2)データの質、 (3)データ収集の迅速性すなわち case report form (CRF) 送付期限の遵守度、(3)プロトコール逸脱 や不適格症例の割合、試験治療の完遂率などの プロトコールコンプライアンス、(4)臨床検査の 施設基準值、(5)有効性の評価、(6)安全性（毒性) の評価、などがある。

登録症例数 図 1 は、Japan Cl inical Oncology Group（JCOG）のある臓器グループにおける 1994 年から 1998 年 8 月の施設別登録症例数を多い順 に示したものである。全参加施設の $12.5 \%$ にた る上位 10 施設からの登録のみで全体の 70\%を占 めており、これは JCOG 全体でも同様の傾向であ った。このことから、施設数を増やすことが単 純に登録症例数の増加にはつながらない可能性 があることがわかる。

データの犋ＣRF に記入されたデータの質にも 大きな施設間差が存在する。図 2 は同一䐵器グ ループの 5 試験において、CRF 中のデータエラー の割合と記入項目数の関係を示したものである。 


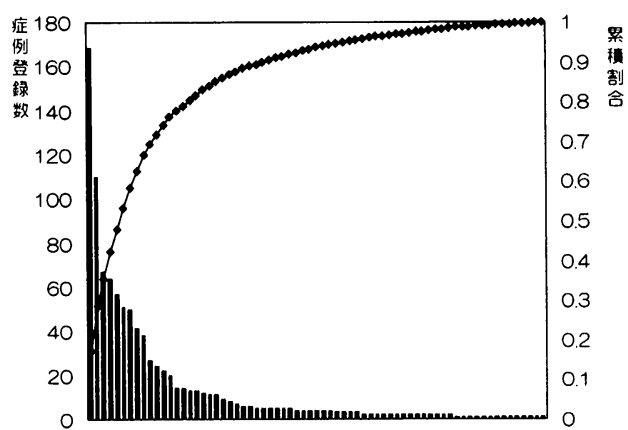

図 $1: 1994$ 年以降の施設別症例登録数

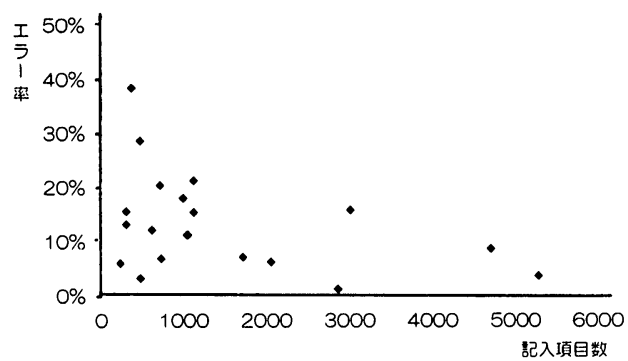

図 $2:$ 施設ごとの記入項目数とデータエラー率

ここでのデータエラーは、未記入（欠損）、誤記、 判読不能、データ間の不整合など、データマネ ージャーが施設への問い合わせが必要と判断し たものと定義した。登録数の多いベテランの施 設ほどデータエラーの割合は低く、たまに症例 を登録する初心者あるいは消極的な施設ではエ ラーが多いといえる。こうしたデータエラーの 施設間差を試験毎、試験の進渉毎に分析するこ とにより、その原因がプロトコールや CRF デザ インによるものかどうかを把握することができ、 早期に対策を講じれば試験全体の質の向上につ ながるであろう。すなわち、施設に関係なくデ ータエラーが多い場合は CRF やプロトコールを 見直すべきであり、データエラーに施設間差が あれば、エラーの多い施設の個別的な対応が必 要と考えられる。

\section{データ収集の迅速性（CRF 送付期限の掽守度）}

CRFをタイムリーに回収し、データの処理·集計 · 解析を行うことは、試験結果の信頼性を高める だけでなく、問題点を早期に発見し、被験者の
安全性を高める上でも非常に重要である。図 3 は JCOG における 1997 年度の追跡調査の調查用 紙回収状況について、指定した期限からの遅れ の平均日数を施設別に示したものである。調査 対象症例数が多いほど時間がかかるはずであり、 正の相関を示すことが予想されたが、実際には 対象症例数が多い施設での遅れは少なかった。 一方、症例数が少ないにもかかわらず大きく遅 れて CRF を返送してきている施設もあり、実際 にはこうした施設がわずかでもあることにより、 データ固定や解析の開始時期が影響を受けるこ とになる。

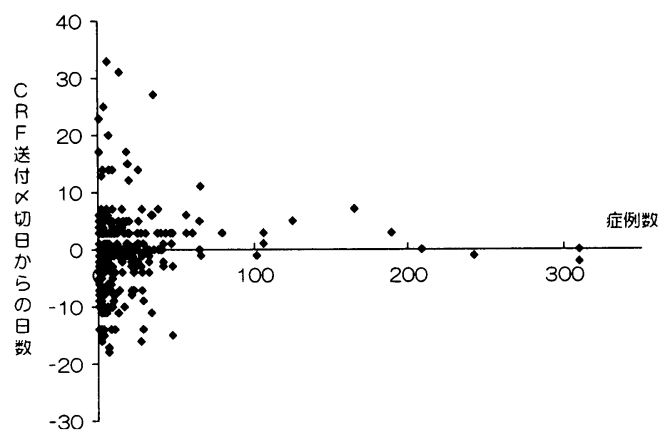

図 $3:$ 施設ごとの登録数と調査用紙の回収の遅れ

有効性の評価 JCOG の同じ疾患を対象にした 3 試験において、登録症例 70 例以上の上位 3 施 設で、CR 率が 2 倍近くも異なっていた（データ 省略)。もちろん患者背景の違いも考えられるが、 評価・判定方法の違いも否定できない。こうし た施設間差を解消するために施設外校閲が施行 される。

\section{【まとめ】}

施設間差は多施設共同臨床試験では不可避で ある。存在することを前提に品質管理を考え、 その施設間差がバイアスなのかランダム誤差な のかを評価することで試験結果に与える影響を 考慮することが重要である。また、実際のデー タマネージメントを評価するツールとして積極 的にこの施設間差を利用し、試験全体の質的向 上に活かすといった発想転換も必要なのではな いだろうか。 